\title{
Molecular Structuring of Novel Chiral Polymers via Cyclophane- based Monomer Design Strategies
}

Henrik Tappert, Zengwen Li, Jasmin Seibert, Christoph Zippel, Zahid Hassan, Stefan Bräse*

Institute of Organic Chemistry (IOC), Karlsruhe Institute of Technology (KIT),

Fritz-Haber-Weg 6, 76131, Karlsruhe, Germany.

Institute of Biological and Chemical Systems (IBCS-FMS), Karlsruhe Institute of Technology (KIT), Hermann-von-Helmholtz-Platz 1, 76344 Eggenstein-Leopoldshafen, Germany.

Email: braese@kit.edu

http://www.ioc.kit.edu/braese/

Abstract: Structuring soft matter with precise control over molecular arrangements, nanoscale morphologies, especially aiming at functional polymers featuring chirality or helicity, responsiveness, and other features, has been a great research objective, which yet remains a challenging task. In this research work, we developed new design strategies for molecular structuring of an entirely new class of chiral polymers based on [2.2]paracyclophane derivatives. The grafting of tunable functional moieties onto [2.2]paracyclophane enables post-polymerization modification, where diverse perspective applications can be envisioned. In particular, chiral vinyl[2.2]paracyclophane and [2.2]paracyclophane-substituted diazoacetate give novel poly[2.2]paracyclophanylethenes and poly[2.2]paracyclophanylmethenes, respectively.

PCP

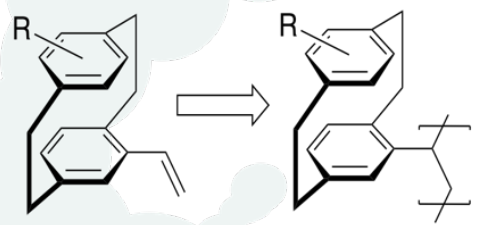

Keywords: Chiral Polymers, Monomer Design, Planar Chirality, [2.2]Paracyclophane 


\section{Introduction}

Chirality is an important concept that is exploited in both naturally occuring and synthetic materials. The distinctive chiral features of molecular systems and their formation mechanisms are of substantial importance from the perspective of emulating nature's approach to supramolecular self-assembly as well as their diverse applications in pharmaceutical, medicinal, and other emerging materials. ${ }^{[1]}$ Chiral moieties can be incorporated into polymers either as backbone or as a side-group attached to the backbone, ultimately aiming for unique properties induced by the chirality. Besides the classical central chirality, other concepts based on helical, planar or supramolecular chirality have been investigated for their applications in life sciences and materials. Different concepts of chirality can be combined into one polymeric structure using suitable chiral monomers. The most commonly used chiral polymers recur to molecules from the chiral pool, which are limited to naturally occuring scaffolds or require multi-step synthetic approaches. ${ }^{[2]}$ Alternatively, chiral polymers need to form and maintain supramolecular structures like helices to prevent the loss of chirality through the formation of meso components. ${ }^{[3,4]}$ The structuring of synthetic materials by a bottom-up dimensional organizing principle, is of utmost relevance sice both structural and complex functional diversity of materials can arise from the inherent physico-chemical properties of the molecular units. For instance, polymer modulation with precise control over the structure, properties, and functions is, among various contributing factors, achieved by the design of the monomers. ${ }^{[5]}$

Assembling customized monomers offers the opportunity to create molecular systems whose structural features and functions can be precisely controlled. To achieve the goal of an easy setup for structuring chiral polymers, in this work, we have envisioned the molecular design and development of novel polymers with a chirality transcription by incorporating chiral [2.2] paracyclophane derivatives into the polymer by employing anionic and radical polymerization with the possibility of postpolymerization modification.

[2.2]Paracyclophane (cyclophanyl; PCP) is is a prevalent 3D scaffold of intriguing structural and electronic properties which exhibits planar chirality upon substitution and is therfore widely investigated in asymmetric synthesis as planar chiral ligands, catalysts, chiroptical, and optoelectronic materials. ${ }^{[6,7]}$ PCP-derived materials dealing with planar chirality and through-space conjugation have been the subject of comprehensive research. ${ }^{[8,9]}$ PCP and derivatives have previously been used in polymer chemistry for the preparation of $\pi$-stacked conjugated polymers by employing electrochemical, transition metal-catalyzed coupling reactions or various polycondensation approaches. ${ }^{[0,11]}$ 
Monomers based on [2.2] paracyclophanes offer intrinsically planar chirality and can be widely functionalized. Grafting synthetically tunable functional moieties can also enable post-polymerization modification for optimizing and tuning structural and functional properties of the polymer. By using carefully chosen reaction parameters and transformation steps, different polymerizable groups can be selectively positioned at either one or both benzene rings of the PCP core to enable polymerization. The wide range of easily accessible modifications with the presented PCP-polymers are shown in Figure 1.

Potential application of the resulting chiral polymers cover, for example, the use as stationary phase in liquid-chromatography for the separation of enantiomers, which is known for polymers based on amylose derivatives, ${ }^{[2]} 3,5$-dinitrobenzoylphenylglycine, ${ }^{[2]}$ or triphenylmethyl methacrylate. ${ }^{[12]}$ The catalytic viablility of PCP has been shown for a variety of asymmertric transforamtions presenting an alternative to conventional central and axial chirality. ${ }^{[13]}$ Transfer of this function and properties of PCP to a polymer allows for an easily recoverable catalyst, which can be further adjusted and optimized. The assembly of chiral supramolecular, polymeric structures makes an application as molecular sensor possible. The construction of supramolecular (chirality) sensing systems for biomolecules, such as amino acids, peptides, and saccharides, is one of the most crucial and challenging topics in current chemistry and is thus of particular significance. ${ }^{[14-16]}$ It is well-known that polymer's tacticity plays a vital importance in its physical properties such as crystallinity, thermal character, conformation, solubility, and morphology. ${ }^{[17]}$ 


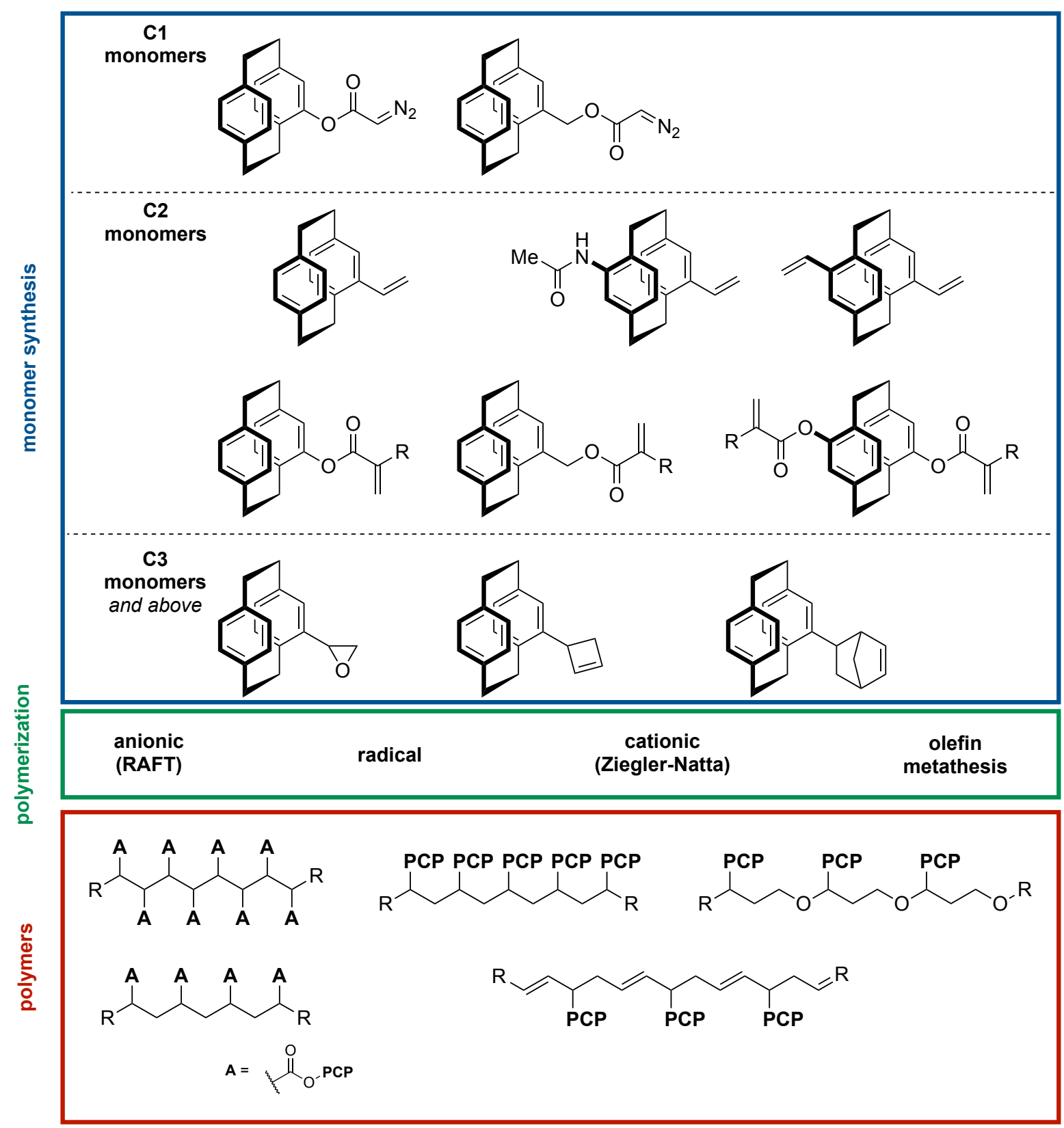

Figure 1: Overview of the synthesized PCP-derived chiral monomers, aimed for polymerizations.

\section{Synthesis of Enantiomerically pure PCP-derived Monomers:}

Of the multitude of possible PCP monomers, we have synthesized a series of enantiomerically pure 4-vinyl[2.2]paracyclophane (3), $\mathrm{N}$-acetyl-4-amino-16-vinyl[2.2]paracyclophane (6), and diazoacetate 4-methyl[2.2]paracyclophane (9) for polymerization.

The styrene analog $\mathbf{3}$ was synthesized according to a previously reported procedure by our group (Figure 2) ${ }^{[19]}$ Starting fromm racemic acetyl-PCP 1, kinetic resolution was employed to separate the enantiomers, followed by elimination to obtain the desired vinyl-PCP 3. 


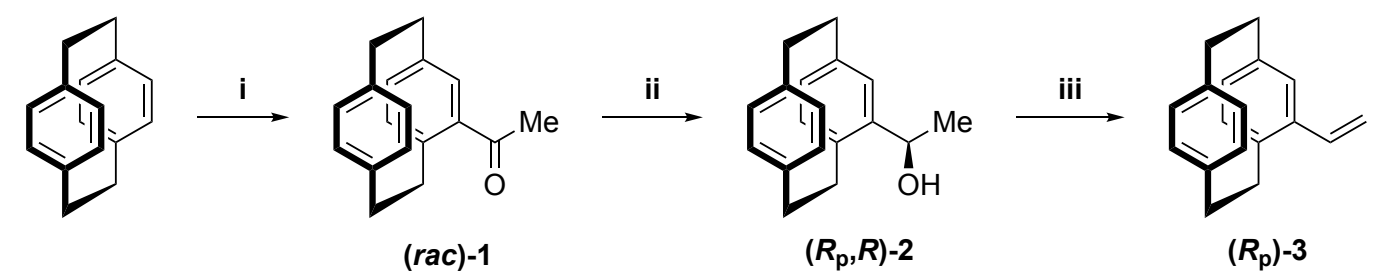

Figure 2: Synthesis of vinyl-PCP 3. Reagents and conditions: i) $\mathrm{AlCl}_{3}, \mathrm{AcCl}_{1} \mathrm{CH}_{2} \mathrm{Cl}_{2},-50$ to $-20^{\circ} \mathrm{C}, 3 \mathrm{~h}$, ii) (S)-RUCY-XylBINAP, $t$-BuOK, $\mathrm{H}_{2}$ (50 bar), $\mathrm{CH}_{2} \mathrm{Cl}_{2}$, r.t., 24 h, iii) $\mathrm{Al}_{2} \mathrm{O}_{3}$, $\mathrm{PhMe}, 120^{\circ} \mathrm{C}, 18 \mathrm{~h}$.

The synthesis of $\mathrm{N}$-acetyl-amino-vinyl-PCP (Figure 3) and diazoacetyl-4-methylPCP (Figure 4) follow similar routes. The use of two equivalents in step a, as depicted in Figure 2, leads to 4,16-diacetyl[2.2]paracyclophane (4) and subsequently into $\left(R_{\mathrm{p}}\right)$-4-acetyl-( $\left.S_{\mathrm{p}}, S\right)-1^{\prime}-(16-$ [2.2]paracyclophanyl)ethanol (5) which can be transformed to the desired product 6 .

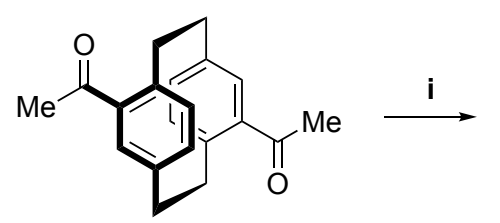

(rac)-4

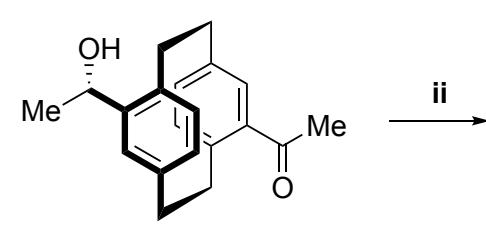

$\left(S_{p}, S\right)-5$

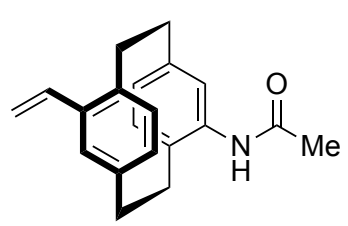

$\left(R_{\mathrm{p}}\right)-6$

Figure 3: Synthesis of $N$-acetyl-amino-PCP 6. Reagents and conditions: i) (R)-RUCY-XylBINAP, $t-B u O K, \mathrm{H}_{2}\left(50\right.$ bar), $\mathrm{CH}_{2} \mathrm{Cl}_{2}, r$.t., $24 \mathrm{~h}$, ii) $\mathrm{HONH}_{2} \cdot \mathrm{HCl}, \mathrm{NaOH}, \mathrm{EtOH}, 90^{\circ} \mathrm{C}, 24 \mathrm{~h}, \mathrm{p}-\mathrm{TsOH}, \mathrm{ZnCl}_{2}, \mathrm{CH}_{3} \mathrm{CN}, 85^{\circ} \mathrm{C}, 3 \mathrm{~h}$.

For the synthesis of diazoacetyl-4-methyIPCP 9, enantiomerically pure 4-hydroxylmethyl[2.2]paracyclophane (7) was produced from 4-formyl[2.2]paracyclophane following an earlier reported procedure, ${ }^{[20]}$ and the desired product was synthesized in two steps via acetoacetyl-PCP product 8.

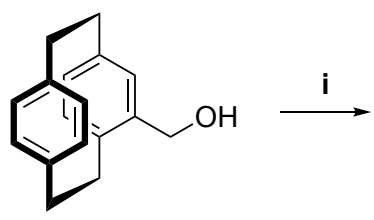

$\left(S_{\mathrm{p}}\right)-7$

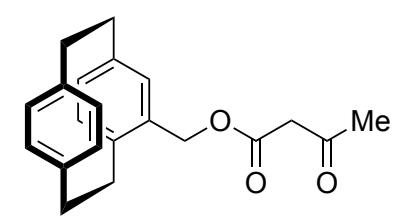

$\left(S_{\mathrm{p}}\right)-8$

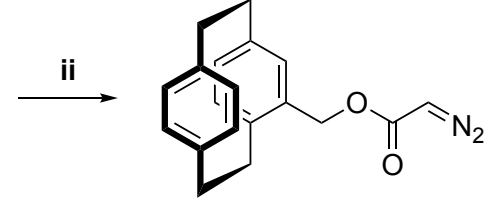

$\left(S_{\mathrm{p}}\right)-9$

Figure 4: Synthesis of diazo acetyl-4-methylPCP 9, Reagents and conditions: a) Diketene acetone adduct, PhMe, $120^{\circ} \mathrm{C} 16 \mathrm{~h}$, b) $\mathrm{TosN}_{3}, \mathrm{CH}_{3} \mathrm{CN}$, TEA, r.t., 16 h, $\mathrm{LiOH}_{(\text {aq) }}$, r.t., 4 h.

Other products, as depicted in Figure 1, are planned to investigate the effects and interactions of side chains and the backbone in chiral PCP-based polymers and to highlight the possibilities for easily varying the structural and complex functions of the polymers. 
For example, the insertion of spacers such as alkyl groups with different lengths, can vary the steric congestion drastically and therefore invoke supramolecular structures. Shorter distances could lead to the forced formation of helices or similar structures, including an additional level of chirality to the polymer. On the other hand, elongating the spacers could benefit polymerization efficiency. The supramolecular structure could be achieved from difunctionalized PCP monomers forming a polymeric network. Also, the backbone can be extended from $\mathrm{C} 1$ and $\mathrm{C} 2$ moieties to $\mathrm{C} 3$ and higher by adjusting the polymerization method. While this mainly affects sterics, additional heteroatoms such as oxygen can also result in altered physico-chemical properties. The insertion of functional groups is also an important possibility to extend the range of PCP polymers currently under investigation in our group. For now, the $\mathrm{N}$-acetyl-amino-vinyl-PCP 6 has been demonstrated and shall serve as proof of concept.

\section{Polymerization Approaches for the Cyclophane-based Monomer:}

The polymerization methods used for the synthesized monomers are anionic, and radical polymerization with $t$-BuLi and AIBN as initiators for vinyl-PCP 3, the same radical procedure for $N$ acetyl-amino-vinyl-PCP 6 and a rhodium-catalyzed diazo polymerization for the C1-polymer made from diazo acetyl-4-methyl-PCP 9 were optimized (Figure 5).
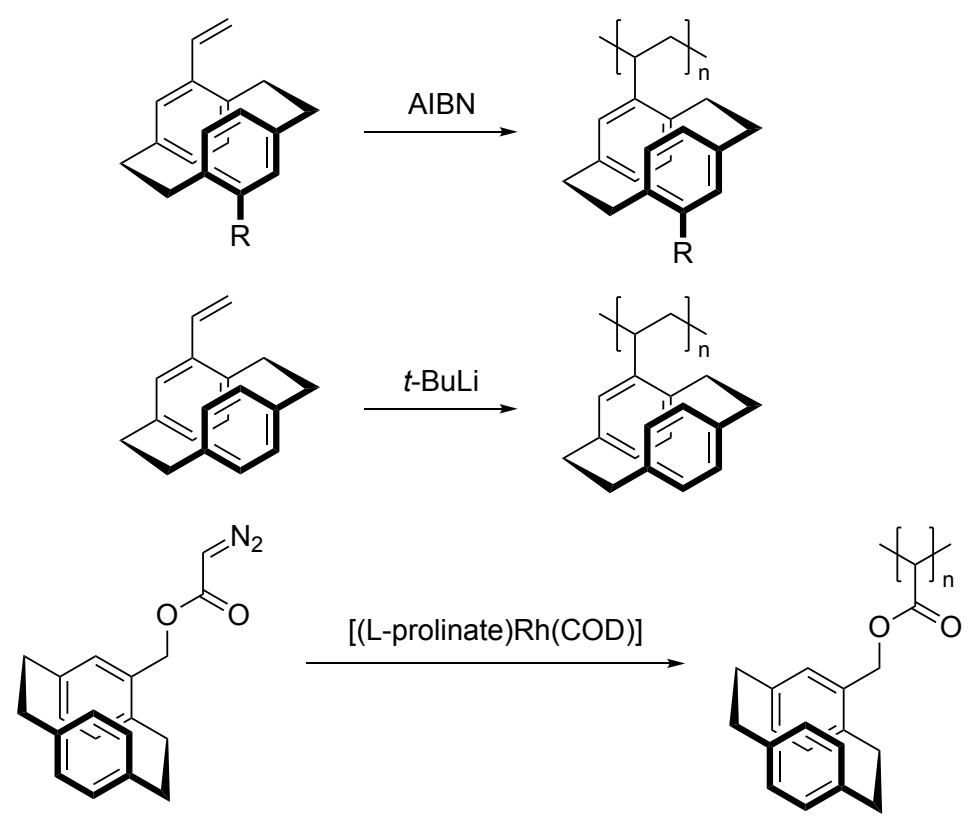

Figure 5: Polymerizations realized as proof of concept. $\mathrm{R}=\mathrm{H}, \mathrm{N}$-acetyl-amine.

Initial polymerization attempts resulted in light molecular weight polymers, with the average molecular weight and polydispersity, as summarized in Table 1 . The chirality of the polymers has been proofed by circular dichroism spectroscopy (CD), as shown for poly(vinyl-PCP) (anionic) in Figure 6. 
Table 1: Weight and distribution of synthesized polymers. $M_{n}=$ average molecular weight, $D=$ polydispersity index.

\begin{tabular}{|c|c|c|c|}
\hline entry & polymer & $\mathrm{M}_{\mathrm{n}}[\mathrm{kDa}]$ & D \\
\hline 1 & $\begin{array}{l}\text { poly(vinyl-PCP) } \\
\text { (anionic) }\end{array}$ & 1.78 kDa & 1.14 \\
\hline 2 & $\begin{array}{l}\text { poly(vinyl-PCP) } \\
\text { (radical) }\end{array}$ & 1.66 kDa & 1.14 \\
\hline 3 & $\operatorname{poly}(N$-acetyl-amino-vinyl-PCP) & $6.44 \mathrm{kDa}$ & 3.71 \\
\hline 4 & poly(acetyl-4-methyl-PCP) & 1.08 kDa & 2.28 \\
\hline
\end{tabular}

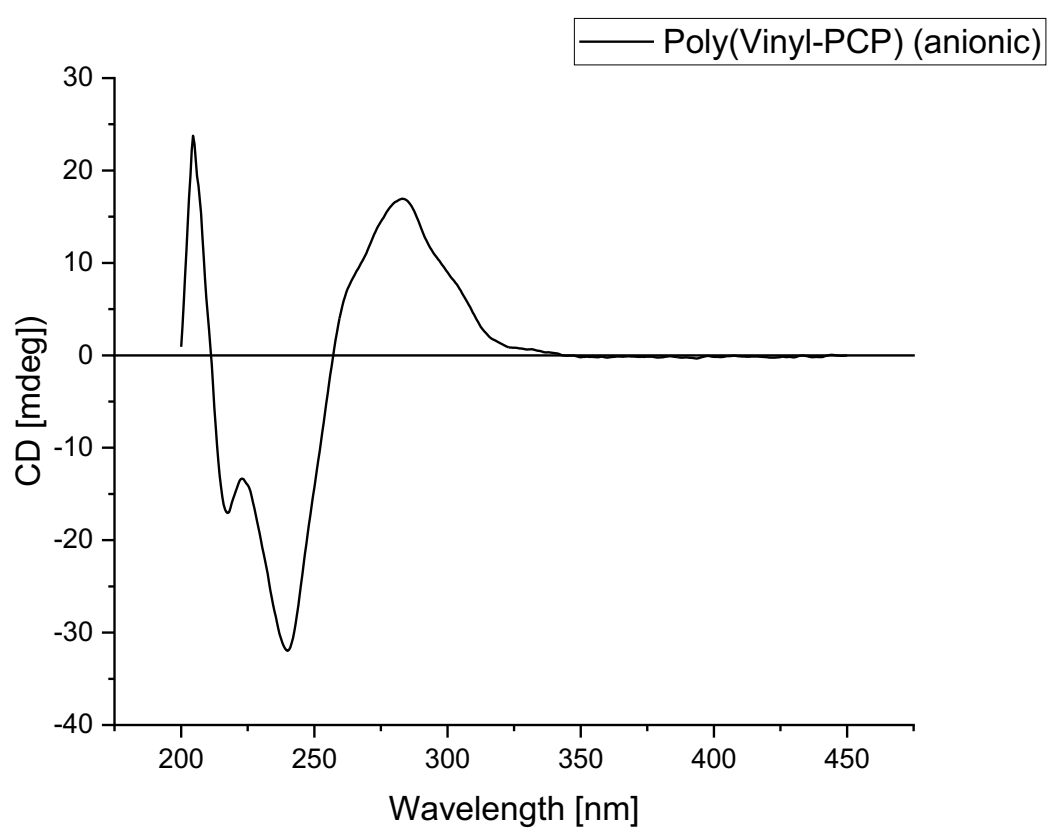

Figure 6: Circular dichroism for poly(vinyl-PCP) produced by anionic polymerization.

\section{Conclusion}

The concept of structuring polymers is evolving beyond the conventional trends with the advent and synergistic combination of new and innovative approaches as well as precursor design strategies. In this work, we have described grafting polymers with ambitious chiral features through incorporating new planar chiral PCP monomers, including 4-vinyl[2.2]paracyclophane, $\mathrm{N}$-acetyl-4-amino-16vinyl[2.2]paracyclophane, and diazoacetate 4-methyl[2.2]paracyclophane based on the key step of an easily scalable kinetic resolution and subsequently polymerization via three different approaches with good results and molecular weights between 1.08 to $6.44 \mathrm{kDa}$. The PCPs inherent chiral features once 
assembled into polymers and grafting synthetically tunable functional moieties to the PCP scaffold, could further enable post-polymerization modifications towards tailor-made chiral polymers. We are interested in studying these new concepts on a larger scale in our ongoing explorations. Furthermore, we plan to extend our efforts to various other PCP-derived monomers and optimize different polymerization methods. We believe this new methodology and the corresponding chiral polymers can be used in catalysis, enantiomer separation, or newer emerging fields like sensing. Studies in these directions are currently underway in our labs.

\section{Acknowledgments}

The authors acknowledge support provided by the the German Research Foundation (formally Deutsche Forschungsgemeinschaft DFG) under Germany's Excellence Strategy in the framework of cluster "3D Matter Made To Order" - 3DMM2O - EXC-2082/1-390761711. We thank the technical and analytical staff at IOC (KIT) for their assistance.

\section{Conflicts of interest}

No conflicts of interest to declare. 


\section{Supporting Information}

\section{General Inforamtion}

\section{Materials and Methods}

The starting materials, solvents, and reagents were purchased from ABCR, ACROS, ALFA AESAR, APOLLO Scientific, Carbolution, Chempur, Fluka, Fluorochem, Merck, Riedel-de HaËn, Sigma Aldrich, Strem, TCl, or THERMO FISHER SCIENTIFIC and used without further purification unless stated otherwise.

Solvents of technical quality were purified by distillation or with the solvent purification system MB SPS5 (acetonitrile, dichloromethane, diethyl ether, tetrahydrofuran, toluene) from MBRAUN. Solvents of p.a. quality were purchased from ACROS, FISHER SCIENTIFIC, SIGMA ALDRICH, Roth, or RIEDEL-DE HAËN and were used without further purification.

Abbreviations: $\mathrm{CyHex}=$ cyclohexane, $\mathrm{EtOAc}=$ ethyl acetate, $\mathrm{DMSO}=$ dimethyl sulfoxide, $\mathrm{iPrOH}=$ iso-propanol, and $\mathrm{PE}_{40 / 60}=$ petrol ether $40 / 60$.

Oxygen-free solvents were obtained by the freeze-pump-thaw (three cycles) technique.

Air- and moisture-sensitive reactions were carried out under argon atmosphere in oven-dried glassware using standard Schlenk techniques.

An MBraun LABmaster with argon atmosphere was used for reaction setups in the glovebox. All materials used were dried for at least $24 \mathrm{~h}$ at $100^{\circ} \mathrm{C}$ before bringing them into the glovebox.

A Berghof BR100 pressure reactor was used for reaction setups under high pressure.

Flat-bottom crimp neck vials from ChromaGlobe with an aluminum crimp cap were used for certain reactions.

Liquids were added with a stainless-steel cannula, and solids were added in powdered shape.

Slow addition of reagents was done with a LANDGRAF LABORSYSTEME model LA100 syringe pump or a DRIFTON LP LSP04-1A.

Reactions at low temperatures were cooled using flat dewars produced by ISOTHERM (Karlsruhe) with water/ice or isopropanol/dry ice mixtures.

Solvents were evaporated under reduced pressure at $45{ }^{\circ} \mathrm{C}$ using a rotary evaporator. For solvent mixtures, each solvent was measured volumetrically.

Flash column chromatography was performed using MERCK silica $60(0.040 \times 0.063 \mathrm{~mm}, 230-400$ mesh ASTM) and quartz sand (glowed and purified with hydrochloric acid). 


\section{Reaction Monitoring}

All reactions were monitored by thin-layer chromatography (TLC) using silica-coated aluminum plates (MERCK, silica 60, F254). UV active compounds were detected with a UV-lamp at $254 \mathrm{~nm}$ and $366 \mathrm{~nm}$ excitation.

When required, vanillin ( $15 \mathrm{~g}$ in $250 \mathrm{~mL}$ ethanol and $2.5 \mathrm{~mL}$ conc. $\left.\mathrm{H}_{2} \mathrm{SO}_{4}\right)$, ninhydrin $(1.5 \mathrm{~g}$ in $100 \mathrm{~mL}$ ethanol and $3.0 \mathrm{~mL}$ acetic acid), Seebach solution (2.5 g phosphomolybdic acid, $1.0 \mathrm{~g} \mathrm{Ce}\left(\mathrm{SO}_{4}\right)_{2}$ in 94 $\mathrm{mL}$ water and $6.0 \mathrm{~mL}$ conc. $\mathrm{H}_{2} \mathrm{SO}_{4}$ ), molybdate phosphate (5\% phosphor molybdic acid in ethanol), potassium permanganate $(0.45 \mathrm{~g}$ potassium permanganate and $2.35 \mathrm{~g}$ of sodium carbonate in $90 \mathrm{ml}$ of water), 2,4-DNP (1.2 g 2,4-dinitrophenyl hydrazine in $8.0 \mathrm{~mL}$ water, $20 \mathrm{~mL}$ ethanol and $6.0 \mathrm{~mL}$ conc. $\mathrm{H}_{2} \mathrm{SO}_{4}$ ) or bromocresol green ( $40 \mathrm{mg}$ in $100 \mathrm{~mL}$ ethanol, $0.1 \mathrm{M}$ sodium hydroxide in water was added until the solution turned blue) was used as TLC-stain.

GC-MS (gas chromatography-mass spectrometry) measurements were performed on an AGILENT TECHNOLOGIES model 6890N (electron impact ionization), equipped with an AGILENT 19091S-433 column ( $5 \%$ phenyl methyl siloxane, $30 \mathrm{~m}, 0.25 \mu \mathrm{m}$ ) and a 5975B VL MSD detector with a turbopump. Helium was used as a carrier gas.

\section{Melting point}

Melting points were detected on an OptiMelt MPA100 device from STANFORD RESEARCH SYSTEM.

\section{Optical Rotation}

Optical rotation was measured with a PERKIN ELMER 241 Polarimeter using a $100 \mathrm{~mm}$ glass cell and a suitable solvent at the sodium-D-lines $\left(589.0\right.$ and $589.6 \mathrm{~nm}$ ) and a constant temperature of $20^{\circ} \mathrm{C}$.

\section{Nuclear Magnetic Resonance Spectroscopy (NMR)}

NMR spectra were recorded on a BRUKER Avance $400 \mathrm{NMR}$ instrument at $400 \mathrm{MHz}$ for ${ }^{1} \mathrm{H} N M R$, $101 \mathrm{MHz}$ for ${ }^{13} \mathrm{C}$ NMR, $376 \mathrm{MHz}$ for ${ }^{19} \mathrm{~F}$ NMR, and $162 \mathrm{MHz}$ for ${ }^{31} \mathrm{P}$ NMR, or a BRUKER Avance $500 \mathrm{NMR}$ instrument at $500 \mathrm{MHz}$ for ${ }^{1} \mathrm{H} N M R, 126 \mathrm{MHz}$ for ${ }^{13} \mathrm{C} \mathrm{NMR}$ and $470 \mathrm{MHz}$ for ${ }^{19} \mathrm{~F} \mathrm{NMR}$ and $202 \mathrm{MHz}$ for ${ }^{31} \mathrm{P} N M R$.

The NMR spectra were recorded at room temperature in deuterated solvents acquired from EURISOTOP, SIGMA ALDRICH, or DEUTERO. The chemical shift $\delta$ is displayed in parts per million [ppm] and the references used were the ${ }^{1} \mathrm{H}$ and ${ }^{13} \mathrm{C}$ peaks of the solvents themselves:

$d_{1}$-chloroform $\left(\mathrm{CDCl}_{3}\right): 7.26 \mathrm{ppm}$ for ${ }^{1} \mathrm{H}$ and $77.16 \mathrm{ppm}$ for ${ }^{13} \mathrm{C}$

$d_{6}$-dimethyl sulfoxide (DMSO- $d_{6}$ ): $2.50 \mathrm{ppm}$ for ${ }^{1} \mathrm{H}$ and $39.52 \mathrm{ppm}$ for ${ }^{13} \mathrm{C}$ 
For the characterization of centrosymmetric signals, the signal's median point was chosen for multiplets the signal range. The following abbreviations were used to describe the proton splitting pattern: $d$ = doublet, $t=$ triplet, $m=$ multiplet, $d d=$ doublet of a doublet, $d d d=$ doublet of doublet of doublet, $d d d d=$ doublet of doublet of doublet of doublet, $\mathrm{dt}=$ doublet of triplet. Absolute values of the coupling constants " $\mathrm{J}$ " are given in Hertz $[\mathrm{Hz}]$ in absolute value and decreasing order. Signals of the ${ }^{13} \mathrm{C}$ spectrum were assigned by distortionless enhancement by polarization transfer (DEPT) spectra DEPT90 and DEPT135 or phase-edited heteronuclear single quantum coherence (HSQC). They were specified in the following way: $+=$ primary or tertiary carbon atoms (positive phase), $-=$ secondary carbon atoms (negative phase), $C_{q}=$ quaternary carbon atoms (no signal).

\section{Infrared Spectroscopy (IR)}

The infrared spectra were recorded with a BRUKER, Alpha P instrument. All samples were measured by attenuated total reflection (ATR). The positions of the absorption bands are given in wavenumbers $\tilde{v}$ in $\mathrm{cm}^{-1}$ and were measured in the range from $3600 \mathrm{~cm}^{-1}$ to $500 \mathrm{~cm}^{-1}$.

Characterization of the absorption bands was done in dependence of the absorption strength with the following abbreviations: vs (very strong, 0-9\%), s (strong, 10-39\%), m (medium, 40-69\%), w (weak, 70-89\%), vw (very weak, 90-100\%).

\section{Mass Spectrometry (MS)}

Electron ionization (EI) and fast atom bombardment (FAB) experiments were conducted using a FINNIGAN, MAT $90(70 \mathrm{eV})$ instrument, with 3-nitrobenzyl alcohol (3-NBA) as matrix and reference for high resolution. For the interpretation of the spectra, molecular peaks $[\mathrm{M}]^{+}$, peaks of protonated molecules $[\mathrm{M}+\mathrm{H}]^{+}$, and characteristic fragment peaks are indicated with their mass-to-charge ratio $(\mathrm{m} / \mathrm{z})$, and their intensity in percent, relative to the base peak $(100 \%)$ is given. In the case of highresolution measurements, the maximum tolerated error is $\pm 5 \mathrm{ppm}$.

$\mathrm{APCl}$ (atmospheric pressure chemical ionization) and ESI (electrospray ionization) experiments were recorded on a Q-Exactive (Orbitrap) mass spectrometer (THERMO FISHER SCIENTIFIC, San Jose, CA, USA) equipped with a HESI II probe to record high resolution. The spectra were interpreted by molecular peaks $[\mathrm{M}]+$, peaks of protonated molecules $[\mathrm{M}+\mathrm{H}]+$, and characteristic fragment peaks and indicated with their mass-to-charge ratio $(\mathrm{m} / \mathrm{z})$. The tolerated error is $\pm 5 \mathrm{ppm}$ of the molecular mass.

\section{Elemental Analysis (EA)}

Elemental analysis was done on an ELEMENTAR vario MICRO instrument. The weight scale used was a SARTORIUS M2P. Calculated and found percentage by mass values for carbon, hydrogen, nitrogen, and sulfur are indicated in fractions of $100 \%$. 


\section{Size Exclusion Chromatography (SEC)}

SEC was performed on a PSS SECcurity2 GPC-System with AGILENT infinity 1260 // hardware. The system used a refractive index detector and tetrahydrofuran with a $1 \mathrm{~mL} / \mathrm{min}$ flow rate at $30^{\circ} \mathrm{C}$ as mobile phase. The measurements were performed with the following column system: PSS SDV analytical $\left(3 \mu \mathrm{m}, 300 \times 8,0 \mathrm{~mm}^{2}, 1000 \AA\right)$ and a PSS SDV analytical precolumn $\left(3 \mu \mathrm{m}, 50 \times 8,0 \mathrm{~mm}^{2}\right)$. Poly(methylmethacrylate) with masses between 102 - 62.200 Da, purchased from PPS, were used. 


\section{Synthetic Procedures}

\section{4-Acetyl[2.2]paracyclophane}

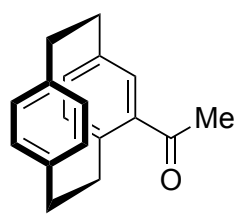

[2.2]Paracyclophane $(7.60 \mathrm{~g}, \quad 36.4 \mathrm{mmol}, 1.00$ equiv.) was dissolved in dichloromethane $(50 \mathrm{~mL})$ and cooled to $-50^{\circ} \mathrm{C}$. A solution of aluminum trichloride ( $8.53 \mathrm{~g}, 64.0 \mathrm{mmol}, 1.75$ equiv.) and acetyl chloride ( $4.95 \mathrm{~g}, 63.0 \mathrm{mmol}, 1.73$ equiv.) in dichloromethane $\left(50 \mathrm{~mL}\right.$ ) was slowly added. After $3 \mathrm{~h}$ at $-20^{\circ} \mathrm{C}$, the solution was poured on ice and stirred until discoloration. The phases were separated, and the aqueous layer was acidified with hydrochloric acid ( $12 \mathrm{M}$ in water), then extracted with dichloromethane $(3 \times 25 \mathrm{~mL})$. The combined organic layers were washed with sodium chloride (sat. aq. solution, $100 \mathrm{~mL}$ ), dried over sodium sulfate, and removed the solvent under reduced pressure. The crude solid was purified by flash column chromatography (silica, $\mathrm{PE}$ 40/60/EtOAc/ $\mathrm{CH}_{2} \mathrm{Cl}_{2}, 20: 1: 1$ ) to yield the title compound (5.48 g, $21.9 \mathrm{mmol}, 60 \%)$ as a colorless solid.

m.p.: $120^{\circ} \mathrm{C}$

$R_{\mathrm{f}}=0.36(n-$ pentane/EtOAc, 10:1)

${ }^{1} \mathrm{H}$ NMR $\left(400 \mathrm{MHz}, \mathrm{CDCl}_{3}, \mathrm{ppm}\right) \delta=6.93\left(\mathrm{~d}, J=1.9 \mathrm{~Hz}, 1 \mathrm{H}, H_{\mathrm{Ar}}\right), 6.66\left(\mathrm{dd}, J=7.8,1.9 \mathrm{~Hz}, 1 \mathrm{H}, H_{\mathrm{Ar}}\right), 6.59$ - $6.46\left(\mathrm{~m}, 4 \mathrm{H}, H_{\mathrm{Ar}}\right), 6.38\left(\mathrm{dd}, J=7.9,1.9 \mathrm{~Hz}, 1 \mathrm{H}, H_{\mathrm{Ar}}\right), 3.97$ (ddd, $\left.J=12.1,7.1,4.5 \mathrm{~Hz}, 1 \mathrm{H}, H_{\mathrm{PC}}\right), 3.25-$ $3.10\left(\mathrm{~m}, 4 \mathrm{H}, H_{\mathrm{Pc}}\right), 3.10-2.97\left(\mathrm{~m}, 2 \mathrm{H}, H_{\mathrm{Pc}}\right), 2.90-2.76\left(\mathrm{~m}, 1 \mathrm{H}, H_{\mathrm{Pc}}\right), 2.47\left(\mathrm{~s}, 3 \mathrm{H}, \mathrm{COCH}_{3}\right)$.

${ }^{13} \mathrm{C}$ NMR $\left(101 \mathrm{MHz}, \mathrm{CDCl}_{3}, \mathrm{ppm}\right) \delta=200.4\left(\mathrm{C}_{\mathrm{q}}, \mathrm{COCH}_{3}\right), 141.7\left(\mathrm{C}_{\mathrm{q}}, \mathrm{C}_{\mathrm{Ar}}\right), 140.4\left(\mathrm{C}_{\mathrm{q}}, \mathrm{C}_{\mathrm{Ar}}\right), 139.9\left(\mathrm{C}_{\mathrm{q}}, \mathrm{C}_{\mathrm{Ar}}\right)$, $139.3\left(C_{q}, C_{A r}\right), 138.0\left(C_{q}, C_{A r}\right), 136.5\left(+, C H, C_{A r}\right), 136.5\left(+, C H, C_{A r}\right), 134.3\left(+, C H, C_{A r}\right), 133.2\left(+, C H, C_{A r}\right)$, $133.0\left(+, \mathrm{CH}, \mathrm{CAr}_{\mathrm{Ar}}\right), 132.2\left(+, \mathrm{CH}, \mathrm{C}_{\mathrm{Ar}}\right), 131.3\left(+, \mathrm{CH}, \mathrm{C}_{\mathrm{Ar}}\right), 36.2\left(-, \mathrm{CH}_{2}\right), 35.3\left(-, \mathrm{CH}_{2}, 2 \mathrm{C}\right), 35.3\left(-, \mathrm{CH}_{2}\right)$, $35.0\left(-, \mathrm{CH}_{2}\right), 28.9\left(+, \mathrm{CH}_{3}\right)$.

IR $\left(A T R, c^{-1}\right) \tilde{v}=3029(w), 3007(w), 2989(w), 2951(w), 2921(m), 2887(w), 2850(w), 1894(v w)$, 1679 (vs), 1643 (w), 1589 (w), 1553 (w), $1494(w), 1483$ (w), 1446 (w), $1431(w), 1409(w), 1349(s)$, $1320(w), 1296$ (w), 1265 (vs), 1241 (m), 1203 (w), $1184(m), 1176(m), 1162(m), 1126(w), 1092(w)$, $1065(w), 1018(w), 983(w), 952(w), 941(w), 918(w), 901(s), 853(v s), 805(w), 793(s), 730(s), 710$ $(\mathrm{m}), 686(\mathrm{w}), 647(\mathrm{~s}), 615$ (vs), $599(\mathrm{~s}), 562(\mathrm{w}), 534(\mathrm{w}), 510(\mathrm{vs}), 492(\mathrm{w}), 458(\mathrm{w}), 397(\mathrm{~m}), 385(\mathrm{w})$. $\mathrm{MS}\left(\mathrm{El}, 70 \mathrm{eV}, 20^{\circ} \mathrm{C}, \%\right) \mathrm{m} / \mathrm{z}=250(85)[\mathrm{M}]^{+}, 146(100)\left[\mathrm{M}-\mathrm{C}_{8} \mathrm{H}_{9}\right]^{+}, 104(81)\left[\mathrm{C}_{8} \mathrm{H}_{8}\right]^{+}$. HRMS (EI, [M] $]^{+}, \mathrm{C}_{18} \mathrm{H}_{18} \mathrm{O}$ ) calcd.: 250.1352, found: 250.1354. 


\section{Kinetic Resolution of 4-Acetyl[2.2]paracyclophane and 1'-(4-[2.2]paracyclophanyl)ethanol}

Inside an argon-filled glovebox, a pressure reactor was charged with 4-acetyl[2.2]paracyclophane (1.00 g, $4.00 \mathrm{mmol}, 1.00$ equiv.), (S)-RUCY ${ }^{\circ}$-XyIBINAP (4.73 mg, $4.00 \mu \mathrm{mol}, 0.10 \mathrm{~mol} \%$ ), potassium tertbutoxide $(44.9 \mathrm{mg}, 0.40 \mathrm{mmol}, 10.0 \mathrm{~mol} \%)$ and anhydrous, degassed dichloromethane $(4.0 \mathrm{~mL})$. Hydrogen was initially introduced into the autoclave at a pressure of 10 bar before being reduced to 1 bar by carefully releasing the stop valve. This procedure was repeated three times, and the vessel was pressurized to 50 bars. The mixture was vigorously stirred $(750 \mathrm{rpm})$ at $22^{\circ} \mathrm{C}$ for $24 \mathrm{~h}$. The autoclave was carefully vented, and the solvent was removed under reduced pressure. The crude solid was purified by flash column chromatography (silica, $n$-pentane/EtOAc/ $\mathrm{CH}_{2} \mathrm{Cl}_{2}, 7: 1: 1$ to $2: 1: 1$ ) to obtain $\quad\left(S_{\mathrm{p}}\right)$-4-acetyl[2.2]paracyclophane $\quad(455 \mathrm{mg}, \quad 1.82 \mathrm{mmol}, \quad 46 \%)$ and $\left(R_{\mathrm{p}}, R\right)-1-(4-$ [2.2]paracyclophanyl)ethanol (440 mg, $1.74 \mathrm{mmol}, 44 \%$ ) as colorless solids.

The analytical data matches that of the corresponding racemic compounds.

$(R)$ - $\mathrm{RUCY}^{\circ}$-XylBINAP gave the same results as the $(S)$-isomer but yielded the opposite stereochemistry in the products, i.e. $\left(R_{\mathrm{p}}\right)$-4-acetyl[2.2]paracyclophane and $\left(S_{\mathrm{p}}, S\right)-1^{\prime}-(4-[2.2]$ paracyclophanyl)ethanol were isolated.

Analytical Chiral HPLC (Chiralcel ${ }^{\circ} \mathrm{OD}-\mathrm{H}, 250 \times 4.6 \mathrm{~mm}, n$-hexane/i-PrOH, 90:10, $1.0 \mathrm{~mL} / \mathrm{min}, \lambda=256$ $\mathrm{nm}): \mathrm{t}_{\mathrm{R}\left(S_{\mathrm{p}} \text {-acetyl) }\right)}=10.0 \mathrm{~min}, \mathrm{t}_{\mathrm{R}\left(R_{p} \text {-acety }\right)}=11.4 \mathrm{~min}, \mathrm{t}_{\mathrm{R}\left(S_{\mathrm{p}}, S\right)}=9.6 \mathrm{~min}, \mathrm{t}_{R\left(R_{p}, R\right)}=13.7 \mathrm{~min}$.

Specific Rotation:

$\left(R_{\mathrm{p}}\right)$-4-Acetyl[2.2]paracyclophane: $[\alpha]_{\mathrm{D}}^{20}\left(\mathrm{CHCl}_{3}, 8 \mathrm{mg} \cdot \mathrm{mL}^{-1},^{\circ} \cdot \mathrm{mL} \cdot \mathrm{dm} \cdot \mathrm{g}^{-1}\right)=-65$

$\left(S_{\mathrm{p}}\right)$-4-Acetyl[2.2]paracyclophane: $[\alpha]_{\mathrm{D}}^{20}\left(\mathrm{CHCl}_{3}, 11 \mathrm{mg} \cdot \mathrm{mL}^{-1},{ }^{\circ} \cdot \mathrm{mL} \cdot \mathrm{dm} \cdot \mathrm{g}^{-1}\right)=+64$

$\left(R_{\mathrm{p}}, R\right)-1^{\prime}-\left(4-[2.2]\right.$ Paracyclophanyl)ethanol: $[\alpha]_{\mathrm{D}}^{20}\left(\mathrm{CHCl}_{3}, 12 \mathrm{mg} \cdot \mathrm{mL}^{-1},{ }^{\circ} \cdot \mathrm{mL} \cdot \mathrm{dm} \cdot \mathrm{g}^{-1}\right)=-27$

$\left(S_{p}, S\right)-1^{\prime}-\left(4-[2.2]\right.$ Paracyclophanyl)ethanol: $[\alpha]_{\mathrm{D}}^{20}\left(\mathrm{CHCl}_{3}, 11 \mathrm{mg} \cdot \mathrm{mL}^{-1},^{\circ} \cdot \mathrm{mL} \cdot \mathrm{dm} \cdot \mathrm{g}^{-1}\right)=+27$

\section{$\left(S_{p}, S\right)-/\left(R_{p}, R\right)-4-V i n y I[2.2]$ paracyclophane}

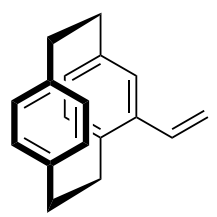

$\left(S_{\mathrm{p}}, S\right) /\left(R_{\mathrm{p}}, R\right)$-1'-(4-[2.2]Paracyclophanyl)ethanol (505 mg, $2.00 \mathrm{mmol}, 1.00$ equiv.) and neutral aluminum oxide $(1.02 \mathrm{~g}, 10.0 \mathrm{mmol}, 5.00$ equiv.) that had been activated at $155^{\circ} \mathrm{C}$ for $18 \mathrm{~h}$ under high vacuum, were suspended in toluene $(30 \mathrm{~mL})$. The mixture was heated to $120^{\circ} \mathrm{C}$ for $18 \mathrm{~h}$ under the removal of water using a DEAN-STARK trap. The solvent was removed under reduced pressure, and the obtained powder was filtered over a short silica plug using $n$-pentane/EtOAc, 4:1 as eluent, to obtain the title compound ( $418 \mathrm{mg}, 1.78 \mathrm{mmol}, 89 \%$ ) as a colorless solid. 
$\left(R_{\mathrm{p}}\right)$-4-Vinyl[2.2]paracyclophane: $[\alpha]_{\mathrm{D}}^{20}\left(\mathrm{CHCl}_{3}, 8 \mathrm{mg} \cdot \mathrm{mL}^{-1},^{\circ} \cdot \mathrm{mL} \cdot \mathrm{dm} \cdot \mathrm{g}^{-1}\right)=-240$

$\left(S_{\mathrm{p}}\right)$-4-Vinyl[2.2]paracyclophane: $[\alpha]_{\mathrm{D}}^{20}\left(\mathrm{CHCl}_{3}, 11 \mathrm{mg} \cdot \mathrm{mL}^{-1},{ }^{\circ} \cdot \mathrm{mL} \cdot \mathrm{dm} \cdot \mathrm{g}^{-1}\right)=+248$

m.p.: $82^{\circ} \mathrm{C}$

$R_{\mathrm{f}}=0.86($ CyHex/EtOAc, 4:1)

${ }^{1} \mathrm{H}$ NMR $\left(500 \mathrm{MHz}, \mathrm{CDCl}_{3}, \mathrm{ppm}\right) \delta=6.81\left(\mathrm{dd}, J=17.4,10.9 \mathrm{~Hz}, 1 \mathrm{H}, \mathrm{CH}_{\text {vinyl }}\right), 6.73(\mathrm{dd}, J=7.8,1.9 \mathrm{~Hz}, 1 \mathrm{H}$, $\left.H_{\text {Ar }}\right), 6.59-6.53\left(\mathrm{~m}, 2 \mathrm{H}, H_{\text {Ar }}\right), 6.53-6.48\left(\mathrm{~m}, 2 \mathrm{H}, H_{\text {Ar }}\right), 6.44\left(\mathrm{~d}, J=7.8 \mathrm{~Hz}, 1 \mathrm{H}, H_{\text {Ar }}\right), 6.41(\mathrm{dd}, J=7.8,1.9$ $\left.\mathrm{Hz}, 1 \mathrm{H}, H_{\text {Ar }}\right), 5.55$ (dd, J = 17.5, $\left.1.4 \mathrm{~Hz}, 1 \mathrm{H}, \mathrm{CH}_{2 \text { vinyl }}\right), 5.30$ (dd, $J=10.9,1.4 \mathrm{~Hz}, 1 \mathrm{H}, \mathrm{CH}_{2}$ viny) $), 3.50$ (ddd, J $\left.=13.6,10.0,1.9 \mathrm{~Hz}, 1 \mathrm{H}, H_{\mathrm{Pc}}\right), 3.18-3.08\left(\mathrm{~m}, 3 \mathrm{H}, H_{\mathrm{Pc}}\right), 3.07-3.01\left(\mathrm{~m}, 1 \mathrm{H}, H_{\mathrm{Pc}}\right), 3.01-2.91\left(\mathrm{~m}, 2 \mathrm{H}, H_{\mathrm{Pc}}\right)$, 2.82 (ddd, $J=13.6,10.4,6.8 \mathrm{~Hz}, 1 \mathrm{H}, H_{\mathrm{Pc}}$ ).

${ }^{13} \mathrm{C}$ NMR $\left(126 \mathrm{MHz}, \mathrm{CDCl}_{3}, \mathrm{ppm}\right) \delta=139.9\left(\mathrm{C}_{\mathrm{q}}, \mathrm{C}_{\mathrm{Ar}}\right), 139.5\left(\mathrm{C}_{\mathrm{q}}, \mathrm{C}_{\mathrm{Ar}}\right), 139.5\left(\mathrm{C}_{\mathrm{q}}, \mathrm{C}_{\mathrm{Ar}}\right), 138.1\left(\mathrm{C}_{\mathrm{q}}, \mathrm{C}_{\mathrm{Ar}}\right), 137.9$ $\left(\mathrm{C}_{\mathrm{q}}, \mathrm{C}_{\mathrm{Ar}}\right), 135.3\left(+, \mathrm{CH}, \mathrm{C}_{\text {viny }} \mathrm{H}\right), 134.9\left(+, \mathrm{CH}, \mathrm{C}_{\mathrm{Ar}}\right), 133.1\left(+, \mathrm{CH}, 2 \mathrm{C}, \mathrm{C}_{\mathrm{Ar}}\right), 132.1\left(+, \mathrm{CH}, \mathrm{C}_{\mathrm{Ar}}\right), 131.9(+, \mathrm{CH}$, $\left.C_{\mathrm{Ar}}\right), 130.2\left(+, \mathrm{CH}, \mathrm{C}_{\mathrm{Ar}}\right), 129.7\left(+, \mathrm{CH}, \mathrm{C}_{\mathrm{Ar}}\right), 114.4\left(-, \mathrm{CH}_{2}, \mathrm{C}_{\text {vinyl }} \mathrm{H}_{2}\right), 35.6\left(-, \mathrm{CH}_{2}\right), 35.3\left(-, \mathrm{CH}_{2}\right), 34.8(-$, $\left.\mathrm{CH}_{2}\right), 33.8\left(-, \mathrm{CH}_{2}\right)$.

IR (ATR, cm $\left.{ }^{-1}\right) \tilde{v}=3087(w), 3031(w), 3007(m), 2986(w), 2948(w), 2925(s), 2918(s), 2891(m), 2847$ (m), $2772(w), 1887(v w), 1827(v w), 1813(v w), 1621(w), 1589(w), 1555(v w), 1497(w), 1482(m)$, $1452(w), 1434(m), 1417(w), 1409(w), 1310(w), 1235(v w), 1221(w), 1203(w), 1183(w), 1157(w)$, 1143 (w), 1105 (vw), 1084 (w), 1055 (vw), 986 (s), 938 (w), 905 (vs), 881 (w), 864 (vs), 810 (m), 793 (s), 748 (vs), 715 (vs), 688 (w), 670 (vs), 628 (s), $569(w), 555(\mathrm{~m}), 507$ (vs), $460(w), 441(w), 422(w), 387$ (w).

MS (El, $\left.70 \mathrm{eV}, 20^{\circ} \mathrm{C}, \%\right) \mathrm{m} / \mathrm{z}=234(35)[\mathrm{M}]^{+}, 130(48)\left[\mathrm{M}-\mathrm{C}_{8} \mathrm{H}_{8}\right]^{+}, 129(100)\left[\mathrm{M}-\mathrm{C}_{8} \mathrm{H}_{9}\right]^{+}, 104(23)\left[\mathrm{C}_{8} \mathrm{H}_{8}\right]^{+}$. HRMS (EI, [M] ${ }^{+}, \mathrm{C}_{8} \mathrm{H}_{18}$ ) calcd.: 234.1409; found: 234.1407.

\section{$\left(R_{\mathrm{p}}\right)$-4-Acetyl-($\left.S_{\mathrm{p}}, S\right)-\mathbf{1}^{\prime}-(16-[2.2]$ paracyclophanyl)ethanol}

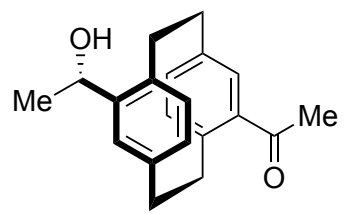

Inside an argon-filled glovebox, a pressure reactor was charged with 4,16-diacetyl[2.2]paracyclophane $(500 \mathrm{mg}, 1.71 \mathrm{mmol}, 1.00$ equiv.), $(R)$ RUCY -XyIBINAP (4.05 mg, $3.42 \mu \mathrm{mol}, 0.20 \mathrm{~mol} \%)$, potassium tert-butoxide (38.4 mg, $0.34 \mathrm{mmol}, 20.0 \mathrm{~mol} \%$ ) and anhydrous, degassed dichloromethane (3.4 mL). Hydrogen was initially introduced into the autoclave at a pressure of 10 bar before being reduced to 1 bar by carefully releasing the stop valve. This procedure was repeated three times, and the vessel was pressurized to $50 \mathrm{bar}$. The mixture was vigorously stirred $(750 \mathrm{rpm})$ at room temperature for $24 \mathrm{~h}$. The autoclave was carefully vented, and the solvent was removed under 
reduced pressure. The crude solid was purified by flash column chromatography (silica, $n$ pentane/EtOAc/ $\mathrm{CH}_{2} \mathrm{Cl}_{2}, 7: 1: 1$ to $2: 1: 1$ ) to obtain the title compound (421 $\mathrm{mg}, 1.43 \mathrm{mmol}, 84 \%$ ) as a colorless solid.

$R_{\mathrm{f}}=0.31$ (n-pentane/EtOAc, 4:1)

$[\alpha]_{\mathrm{D}}^{20}\left(\mathrm{CHCl}_{3}, 19.1 \mathrm{mg} \cdot \mathrm{mL}^{-1},{ }^{\circ} \cdot \mathrm{mL} \cdot \mathrm{dm} \cdot \mathrm{g}^{-1}\right)=-18$

${ }^{1} \mathrm{H}$ NMR $\left(500 \mathrm{MHz}, \mathrm{CDCl}_{3}, \mathrm{ppm}\right) \delta=\delta 6.92\left(\mathrm{~d}, J=1.9 \mathrm{~Hz}, 1 \mathrm{H}, H_{\mathrm{Ar}}\right), 6.83\left(\mathrm{dd}, J=7.8,1.9 \mathrm{~Hz}, 1 \mathrm{H}, H_{\text {Ar }}\right), 6.67$ $\left(\mathrm{d}, J=1.9 \mathrm{~Hz}, 1 \mathrm{H}, H_{\text {Ar }}\right), 6.51\left(\mathrm{~d}, J=7.7 \mathrm{~Hz}, 1 \mathrm{H}, H_{\text {Ar }}\right), 6.44$ (dd, J= 7.7, $\left.1.9 \mathrm{~Hz}, 1 \mathrm{H}, H_{\text {Ar }}\right), 6.30(\mathrm{~d}, J=7.8 \mathrm{~Hz}$, $\left.1 \mathrm{H}, H_{\mathrm{Ar}}\right), 4.93\left(\mathrm{q}, J=6.4 \mathrm{~Hz}, 1 \mathrm{H}, \mathrm{CHCH}_{3}\right), 3.96$ (ddd, $J=12.5,9.6,2.6 \mathrm{~Hz}, 1 \mathrm{H}, H_{\mathrm{PC}}$ ), 3.32 (ddd, $J=13.4$, 8.9, 4.3 Hz, 1H, $\left.H_{\mathrm{Pc}}\right), 3.24-3.07\left(\mathrm{~m}, 4 \mathrm{H}, H_{\mathrm{Pc}}\right), 2.97-2.79\left(\mathrm{~m}, 2 \mathrm{H}, H_{\mathrm{Pc}}\right), 2.47\left(\mathrm{~s}, 3 \mathrm{H}, \mathrm{CH}_{3}\right), 1.70(\mathrm{~s}, 1 \mathrm{H}$, $\mathrm{OH}), 1.31\left(\mathrm{~d}, J=6.4 \mathrm{~Hz}, 3 \mathrm{H}, \mathrm{CHCH}_{3}\right)$.

${ }^{13} \mathrm{C}$ NMR $\left(126 \mathrm{MHz}, \mathrm{CDCl}_{3}, \mathrm{ppm}\right) \delta=200.4\left(\mathrm{C}_{\mathrm{q}}, \mathrm{COCH}_{3}\right), 144.8\left(\mathrm{C}_{\mathrm{q}}, \mathrm{C}_{\mathrm{Ar}}\right), 141.8\left(\mathrm{C}_{\mathrm{q}}, \mathrm{C}_{\mathrm{Ar}}\right), 141.0\left(\mathrm{C}_{\mathrm{q}}, \mathrm{C}_{\mathrm{Ar}}\right)$, $139.5\left(C_{q}, C_{A r}\right), 138.4\left(C_{q}, C_{A r}\right), 135.9\left(+, C H, C_{A r}\right), 134.7\left(C_{q}, C_{A r}\right), 134.2\left(+, C H, C_{A r}\right), 134.0\left(+, C H, C_{A r}\right)$, $133.8\left(+, \mathrm{CH}, \mathrm{C}_{\mathrm{Ar}}\right), 129.9\left(+, \mathrm{CH}, \mathrm{CAr}_{\mathrm{Ar}}\right), 128.3\left(+, \mathrm{CH}, \mathrm{C}_{\mathrm{Ar}}\right), 68.1\left(+, \mathrm{CH}, \mathrm{CHCH}_{3}\right), 35.6\left(-, \mathrm{CH}_{2}\right), 34.7\left(-, \mathrm{CH}_{2}\right)$, $34.1\left(-, \mathrm{CH}_{2}\right), 32.4\left(-, \mathrm{CH}_{2}\right), 28.9\left(+, \mathrm{CH}_{3}\right), 26.3\left(+, \mathrm{CH}, \mathrm{CHCH}_{3}\right)$.

IR (ATR, cm $\left.{ }^{-1}\right) \tilde{v}=3548(w), 2983(w), 2949(w), 2929(m), 2894(w), 2854(w), 1655$ (vs), $1592(w)$, $1551(w), 1482(w), 1452(w), 1434(w), 1425$ (w), 1354 (s), 1339 (m), 1302 (w), 1289 (w), 1264 (vs), $1254(s), 1200(m), 1184(w), 1164(w), 1149(w), 1132(w), 1112(m), 1060(s), 1020(s), 990(w), 975$ (w), $952(\mathrm{~m}), 933(\mathrm{w}), 916(\mathrm{w}), 902(\mathrm{~s}), 873(\mathrm{~m}), 860(\mathrm{~m}), 829(\mathrm{w}), 816(\mathrm{w}), 793(\mathrm{w}), 762(\mathrm{w}), 744(\mathrm{w})$, $727(\mathrm{~m}), 711(\mathrm{w}), 686(\mathrm{w}), 656(\mathrm{~s}), 642(\mathrm{w}), 612(\mathrm{~s}), 598(\mathrm{~s}), 569(\mathrm{w}), 537(\mathrm{~m}), 507(\mathrm{vs}), 477(\mathrm{~s}), 460(\mathrm{~m})$, $439(\mathrm{~s}), 415(\mathrm{~m}), 392(\mathrm{~m})$.

HRMS (APCI, [M] ${ }^{+}, \mathrm{C}_{20} \mathrm{H}_{23} \mathrm{O}_{2}$ ) calcd.: 295.1693, found: 295.1688 .

\section{$\left(R_{\mathrm{p}}\right)$-N-Acetyl-4-amino-( $\left.S_{\mathrm{p}}\right)$-16-vinyl[2.2]paracyclophane}

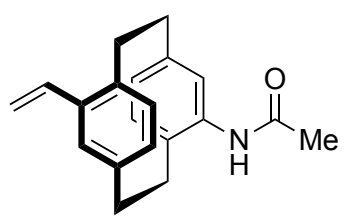

Hydroxylamine hydrochloride (228 $\mathrm{mg}, 3.28 \mathrm{mmol}, 3.00$ equiv.), sodium hydroxide (136 mg, $3.39 \mathrm{mmol}, 3.10$ equiv.) and $\left(R_{\mathrm{p}}\right)$-4-acetyl-( $\left.S_{\mathrm{p}}, S\right)-1^{\prime}-$

(16-[2.2]paracyclophanyl)ethanol (322 $\mathrm{mg}, 1.09 \mathrm{mmol}, 1.00$ equiv.) in ethanol $(15 \mathrm{~mL})$ were stirred at $90^{\circ} \mathrm{C}$ for $24 \mathrm{~h}$. The reaction mixture was diluted with ethyl acetate $(10 \mathrm{~mL})$ and water $(20 \mathrm{~mL})$ and extracted with ethyl acetate $(3 \times 20 \mathrm{~mL})$, washed with brine, and dried over $\mathrm{Na}_{2} \mathrm{SO}_{4}$. The crude solid was redissolved in acetonitrile $(11 \mathrm{~mL})$ and p-toluenesulfonic acid monohydrate (20.8 mg, $109 \mu \mathrm{mol}, 0.100$ equiv.) and zinc dichloride $(17.9 \mathrm{mg}$, $131 \mu \mathrm{mol}, 0.120$ equiv.) were added. The mixture was heated to $85^{\circ} \mathrm{C}$ for $3 \mathrm{~h}$. The solvents were removed under reduced pressure, and the crude solid was purified by column chromatography 
( $n$-pentane/EtOAc 1:1 + 1\% TEA) to obtain the title compound $(62.4 \mathrm{mg}, 214 \mu \mathrm{mol}, 20 \%$ ) as a colorless solid.

$R_{\mathrm{f}}=0.28(n$-pentane/EtOAc, $1: 1)$

${ }^{1} \mathrm{H}$ NMR $(500 \mathrm{MHz}, \mathrm{DMSO}, \mathrm{ppm}) \delta=9.24(\mathrm{~s}, 1 \mathrm{H}, N \mathrm{H}), 6.83\left(\mathrm{dd}, J=17.4,11.0 \mathrm{~Hz}, 1 \mathrm{H}, H_{\mathrm{Ar}}\right), 6.69(\mathrm{dd}, J=$ $\left.7.7,1.9 \mathrm{~Hz}, 1 \mathrm{H}, H_{\text {Ar }}\right), 6.53\left(\mathrm{dd}, J=20.8,1.9 \mathrm{~Hz}, 2 \mathrm{H}, H_{\text {Ar }}\right), 6.45-6.36\left(\mathrm{~m}, 2 \mathrm{H}, H_{\text {Ar }}\right), 6.31(\mathrm{~d}, J=7.7 \mathrm{~Hz}, 1 \mathrm{H}$, $H_{\text {Ar }}$ ), 5.55 (dd, $\left.J=17.4,1.6 \mathrm{~Hz}, 1 \mathrm{H}, \mathrm{CH}_{2, \text { viny }}\right), 5.27$ (dd, $J=11.0,1.5 \mathrm{~Hz}, 1 \mathrm{H}, \mathrm{CH}_{2, \text { vinyl }}$ ), 3.41 (ddd, $J=12.8$, 10.0, $\left.2.2 \mathrm{~Hz}, 1 \mathrm{H}, H_{\mathrm{PC}}\right), 3.31-3.23\left(\mathrm{~m}, 1 \mathrm{H}, H_{\mathrm{PC}}\right), 2.99-2.88\left(\mathrm{~m}, 3 \mathrm{H}, H_{\mathrm{PC}}\right), 2.83$ (ddd, $J=12.9,10.0,6.0$ $\left.\mathrm{Hz}, 1 \mathrm{H}, H_{\mathrm{PC}}\right), 2.77-2.62\left(\mathrm{~m}, 2 \mathrm{H}, H_{\mathrm{PC}}\right), 2.12\left(\mathrm{~s}, 3 \mathrm{H}, \mathrm{CH}_{3}\right)$.

\section{$\left(\mathrm{S}_{\mathrm{p}}\right)$-Acetoacetate 4-methyl[2.2]paracyclophane}

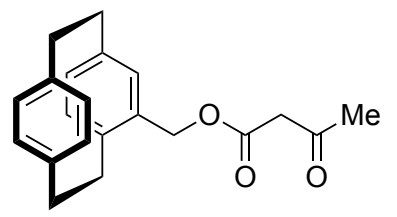

[( $\left.S_{p}\right)$-4-Hydroxymethyl[2.2]paracyclophane $(2.78 \mathrm{~g}, 8.62 \mathrm{mmol}, 1.00$ equiv.) and 2,2,6-trimethyl-4H-1,3-dioxin-4-one $(1.22 \mathrm{~g}, 1.14 \mathrm{~mL}, 8.62 \mathrm{mmol}$, 1.00 equiv.) were dissolved in toluene $(50 \mathrm{~mL})$ and heated to $110{ }^{\circ} \mathrm{C}$ for $16 \mathrm{~h}$. The solvent was removed under reduced pressure, and the crude product was used without further purification in the next step.

\section{$\left(S_{\mathrm{p}}\right)$-Diazoacetate 4-methyl[2.2]paracyclophane}

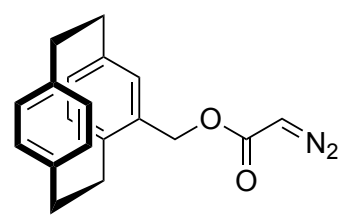

Tosyl azide ( $2.21 \mathrm{~g}, 11.2 \mathrm{mmol}, 1.30$ equiv.) was dissolved in acetonitrile (30 $\mathrm{mL}$ ) was dropwise added over $30 \mathrm{~min}$ to a solution of $\left(S_{p}\right)$-4-ylmethylacetoacetate[2.2]paracyclophane $(2.78 \mathrm{~g}, \quad 8.62 \mathrm{mmol}, 1.00$ equiv. $)$ and triethylamine (1.32 mL, $9.48 \mathrm{mmol}, 1.10$ equiv.) in acetonitrile $(80 \mathrm{~mL})$. After $16 \mathrm{~h}$ at room temperature, lithium hydroxide ( $413 \mathrm{mg}, 17.3 \mathrm{mmol}, 3.00$ equiv.) in deionized water was added, and the mixture was stirred for 4 hours. The crude product was extracted three times with diethyl ether. All the organic phases were combined, washed with water, and dried over $\mathrm{MgSO}_{4}$. The solvent was removed under reduced pressure, and the crude residue was purified by column chromatography with dichloromethane as eluent. The titele compounde $(2.10 \mathrm{~g}, 6.85 \mathrm{mmol}, 80 \%)$ was obtained as a yellow solid.

${ }^{1} \mathrm{H} \mathrm{NMR}\left(500 \mathrm{MHz}, \mathrm{CDCl}_{3}, \mathrm{ppm}\right) \delta=6.40-6.64(\mathrm{~m}, 7 \mathrm{H}), 5.19-5.21(\mathrm{~d}, 1 \mathrm{H}), 4.97-5.00(\mathrm{~d}, 1 \mathrm{H}), 4.79(\mathrm{~s}, 1 \mathrm{H})$, 2.90-3.38 (m, 8H). 


\section{General polymerization procedures}

Anionic polymerization:

Under an argon atmosphere, a solution of the PCP monomer (500 mg, $1.00 \mathrm{eq}$ ) and $t$-BuLi (up to 0.10 equiv.) in dry, degassed toluene was stirred for $24 \mathrm{~h}$ at $0{ }^{\circ} \mathrm{C}$. The product was precipitated with a tenfold excess of methanol. Subsequently, the polymer was dissolved in toluene and precipitated with methanol to yield a white solid.

Radical polymerization:

Under an argon atmosphere, a solution of the PCP monomer (500 mg, 1.00 equiv.) and AIBN (up to 0.10 equiv.) in dry, degassed toluene was stirred for $24 \mathrm{~h}$ at $60{ }^{\circ} \mathrm{C}$. The product was precipitated with a tenfold excess of methanol. Subsequently, the polymer was solved in toluene and precipitated with methanol to yield a white solid

Polymerization of diazo compounds:

[(L-prolinate)Rh(COD)] (0.02 equiv.) was dissolved in chloroform. Subsequently, a diazo-functionalized PCP monomer (1.00 equiv.) dissolved in chloroform was added. The reaction mixture was stirred for at least 14 hours or longer until GC indicated that all starting monomers had been converted. Then the solvent was evaporated under vacuum, and oily residuals were precipitated three times in hexane. 


\section{References}

[1] L. D. Barron, Sp. Sci. Rev. 20071351 2007, 135, 187-201.

[2] E. R. Francotte, J. Chromatogr. A 2001, 906, 379-397.

[3] J. J. L. M. Cornelissen, A. E. Rowan, R. J. M. Nolte, N. A. J. M. Sommerdijk, Chem. Rev. 2001, $101,4039-4070$.

[4] E. Yashima, K. Maeda, H. Lida, Y. Furusho, K. Nagai, Chem. Rev. 2009, 109, 6102-6211.

[5] J. F. Lutz, J. M. Lehn, E. W. Meijer, K. Matyjaszewski, Nat. Rev. Mater. 201615 2016, 1, 1-14.

[6] Z. Hassan, E. Spuling, D. M. Knoll, J. Lahann, S. Bräse, Chem. Soc. Rev. 2018, 47, 6947-6963.

[7] Z. Hassan, E. Spuling, D. M. Knoll, S. Bräse, Angew. Chemie Int. Ed. 2020, 59, 2156-2170.

[8] O. R. P. David, Tetrahedron 2012, 68, 8977-8993.

[9] Z. Hassan, S. Bräse, Chem. - A Eur. J. 2021, 27, 15021-15027.

[10] Y. Morisaki, Y. Chujo, Angew. Chemie Int. Ed. 2006, 45, 6430-6437.

[11] H. Hopf, Angew. Chemie Int. Ed. 2008, 47, 9808-9812.

[12] T. Nakano, J. Chromatogr. A 2001, 906, 205-225.

[13] a) J. Paradies, Synthesis 2011, 2011, 3749-3766. b) Z. Hassan, E. Spuling, D. M. Knoll, J. Lahann, S. Bräse, Chem. Soc. Rev. 2018, 47, 6947-6963.

[14] M. Li, G. Qing, M. Zhang, T. Sun, Sci. China Chem. 2014, 57, 540-551.

[15] K. Ariga, G. J. Richards, S. Ishihara, H. Izawa, J. P. Hill, Sensors 2010, 10, 6796-6820.

[16] G. Fukuhara, Polym. J. 2015, 47, 649-655.

[17] P. N. Tzounis, D. V. Argyropoulou, S. D. Anogiannakis, D. N. Theodorou, Macromolecules 2018, 51, 6878-6891.

[18] N. M. G. Franssen, J. N. H. Reek, B. de Bruin, Chem. Soc. Rev. 2013, 42, 5809-5832.

[19] C. Zippel, Z. Hassan, A. Q. Parsa, J. Hohmann, S. Bräse, Adv. Synth. Catal. 2021, 363, 28612865.

[20] M. L. Delcourt, S. Turcaud, E. Benedetti, L. Micouin, Adv. Synth. Catal. 2016, 358, 1213-1218. 